\title{
LIFE AND FERTILITY
}

Szczepan Szpoton, Rev., PhD, https:// orcid.org/0000-0002-2609-256X

Faculty of Theology

Pontifical University of John Paul II in Krakow

\section{Environmental Ecology versus Human Ecology Ekologia środowiska a ekologia ludzka ${ }^{1}$}

\author{
https://doi.org/10.34766/fetr.v47i3.948
}

\begin{abstract}
A collation of environmental ecology with human ecology was the essence of the article. The field of the research included the topics: blending the range of care for ecosystem with the responsibility for our own human nature; presenting the connection between sexuality and procreation concentrated on the gift of marital unity yet protecting the dignity of human procreation; pointing at the areas of human life where the "ecological conversion" takes place.

Key words: ecology, sexuality, procreation, conjugal/married love, „ecological conversion"
\end{abstract}

Abstrakt: Treścią artykułu było zestawienie ekologii środowiska z ekologią człowieka. Pole badań obejmowało tematy: łączenie zakresu troski o ekosystem z odpowiedzialnością za własną ludzką naturę; ukazanie związku między seksualnością a prokreacją, skoncentrowanego na darze jedności małżeńskiej, ale chroniącej godność ludzkiej prokreacji; wskazując na obszary życia człowieka, w których dokonuje się „nawrócenie ekologiczne”

Słowa kluczowe: ekologia, seksualność, prokreacja, miłość małżeńska, „nawrócenie ekologiczne”

\section{Introduction}

French writer Jean Guitton in his Essay on Human Love edited in 1955 presents a thought which is a perfect starting point for the reflection introduced by the title of this article. He writes: "Likewise a breath proves the existence of the atmosphere so love needs the existence of something which we could call 'erosphere'" (Guitton, 1995: 90). Thus, according to him human love requires a special sphere which would allow it to live, understand itself and develop. Otherwise, it lacks oxygen and chokes. Guitton calls this space 'erosphere' and to define it he notices that a human being cannot really love not being dipped in something bigger than them, in some higher unity that surpasses them. This thought also refers to an unbeliever who does not participate in the cult; love always remains a religious reality: "It (love) surpasses mutual ecstasy, where it takes its beginning, in order

${ }^{1}$ Polska wersja: https:/ / stowarzyszeniefidesetratio.pl/Presentations0/2021-3-Szpo.pdf 
to ascend to adoration unique in its kind" (ibid.). Only this way can the personalization of love which gets oriented on something higher take place.

At the starting point a question has been asked: What has happened to human love? It might be claimed that erosphere undergoes contamination, a phenomenon analogical to an ozone hole which evokes so much concern nowadays. Love loses its cosmic and mystical dimension, its religious and personal openness. Eros is in agony - sociologists and philosophers claim (Byung-Chul, 2013; Bauman, 2013).

A real paradox is that: on the one hand you are constantly being alarmed about deteriorating biological ecosystem condition, and on the other, a reflection on the human environment, which is also endangered by contamination, does not come to mind at all. Yet, it is the one which enables a human being to love, thus men and women can live as persons. ${ }^{2}$ What is more, radical ecologism suggests solving the ecological problem by technical manipulation with sexuality happening by complete separating sexuality from procreation by using contraception, abortion and assisted reproduction, or more, by claiming radical body flexibility in the gender ${ }^{3}$ theory.

In this study the matter of fertility has been referred to - the topic articulated suggestively in the encyclical Humanae Vitae of St. Paul VI, in the context of human ecology that enables a man and a woman to protect this erosphere, which is so necessary for love. This will allow for the confrontation of Humanae Vitae with pope Francis' Laudato si'. This will give an opportunity not only to listen to its teaching but also to undertake a reflection which was not depicted directly in the encyclical. This reflection encompasses three elements. Firstly, basic topics of human ecology with reference to body and relations. Secondly, a strong association between marriage anastomosis and parenthood, inscribed in the nature of human love. Thirdly, what are the choices that really strengthen love and are 'eco-compatible with erosphere which should breathe.

\section{Contamination of erosphere and human love.}

To start with, the papal teaching on ecology of love should be brought to the table, including the encyclical Laudato si'. The first pope who referred to the topic was Paul VI - a great pope of Humanae Vitae, who coined the term "human ecology" with reference to human fertility during the audience on $7^{\text {th }}$ November 1973. He explicitly connected them with the things that " $(. .$.$) cause unrest in the heart and infect the soul with pornography,$ immoral shows and dissolute performances" (Paul VI, 1973). At that time, it seemed to be a simple care, a consequence of old-fashioned puritan mentality, but today when we can see

\footnotetext{
2 Francis' encyclical Laudato si' also draws attention to this paradox, no 136 (henceforth: LS).

${ }_{3}$ Professor Thomas Hilgers, in Chapter I of his textbook on NaProTECHNOLOGY, thoroughly discusses these processes, "soutions", cf. Hilgers, 2004, pp. 1-17.
} 
how many new addictions and destructions are caused by pornography, one must admit that it was a prophetic warning (Kuby, 2013: 185-204).

Later - in a wider form - this topic was discussed by St. John Paul II in the encyclical Centesimus Annus from 1991 (no 37-39). He pointed that there is a much more serious from the pollution of nature - i.e. the destruction of human environment, especially the one which affects a person in a family. Family is thus the "place", the environment (Ethos) in which a woman/ a man is born to live her/ his own humanity, becomes herself/ himself growing in relationships with others and with God. A radical danger for humanum comes mainly when fertility or sexuality is being manipulated, by taking control over the sources of life and over life being born by using contraception and practice of induced abortions. This way we come to face a real "chemical war" which is able to pollute relations and love.

The Polish pope also points out a basic anthropological mistake which is hidden behind the environmental destruction - i.e. forgetting the fact that human action aiming at the transformation of nature, mainly human nature, should always take place "(...) based on God's prior and original gift of the things that are" (ibid.: no 37). This way he determines a moral criterion of natural law to human action which was properly defined by cardinal Carlo Caffarra as “(...) covenant with creative wisdom" (Caffarra, 2006: 81-82). When a human rejects the covenant, instead of becoming a collaborator of God in the act of creation, $\mathrm{s} /$ he puts herself/ himself in His place, sooner or later starting to provoke the nature which rebels. And, as pope Francis rightly notices on many occasions: "God always forgives, we men forgive sometimes, but nature never does" (Francis, 2021).

There were many times when pope Benedict XVI dealt with the topic of the ecology of love - especially the family one. It is worth mentioning one of his last speeches given to the Roman Curia during Christmas greetings on 21 st December 2012. Then he pointed particular attention at the family matter, which is radically contested in its natural constitution as the relation based on marriage understood as a permanent wedlock of a man and a woman, which aims at giving birth and bringing up children. He stated that in this matter not only a specific social form is vital, but also a man in her/his basic dignity. If this relation is rejected, then "(...) fundamental figures disappear from a human existence: father, mother, child" (Benedict XVI, 2012). Manipulating family relationship is dangerous to human dignity, which may thus become an easy and undefended prey to anonymous authority (Seewald, 2021, 912-921).

From the encyclical Laudato $\mathrm{si}^{\prime}$, the first one which is dedicated explicitly to the topic of ecology, one can take advantage of some teachings of pope Francis referring to his predecessors and emphasizing the relationship between environmental ecology and human ecology. He mentioned in particular two verbs connected with the proper attitude to the creation, which are present in the description included in the Book of Genesis, namely: "grow and nurture" (LS 124). There is a reference to the idea of a wise order imprinted in the 
nature. As God's creation, it carries a message imprinted in its structures, which should be read and respected (LS 117); it is a fruit of wisdom and not an effect of a blind and random evolution (LS 68-69).

Basically though, no 155 is the text which is worth exposing as a real pearl placed in this document as it contributes to the most interesting insights to the topic discussed. Human ecology is mainly spoken of there, and - bringing back the teaching of Benedict XVI - it mentions that a man has a certain nature and should respect a certain law imprinted in this nature. The reason is that the fundament of authentic human ecology is noticed just in body, which is a source of relationship not only with the environment but also, and mainly, with other human beings and God. In particular, thanks to sexual diversity imprinted in each body, the relationships which are important for the identity of every human can be established, the ones connected with being sons and daughters, husbands and wives, fathers and mothers. If body is determined by the logic of domination and manipulation without respect for the natural moral law, it will give a prerequisite for destruction of any human ecology (Benedict XVI, 2011, p. 41).

Therefore, synthetically considering the topic, one can say that ecological care in the latest teaching of the Church strongly underlines necessity of combining present care of ecosystem with more fundamental responsibility for human own nature. The human body cannot be seen as a matter subjected to manipulation. It is a personal reality being open to the world and to others, it is the place where identity of a subject is gradually created responding to the call to love in the web of relationships offered and built with others. Those relationships find their own expression and are nurtured especially in a family. Human ecosystem has its delicate and precious place in a family where it is protected and can be developed. It is within a family that its members keep a memory of the gift of life and original meanings which the Creator imprinted in His creations when He was making them a man and a woman.

Surprisingly, provoked by a heated discussion over the family which was evoked by the exhortation Amoris laetitia, Prof. Eberhard Schockenhoff, an influential moralist theologian from the University of Freiburg in Breisgau claimed that following the indications of the pope moral theology we should "(...) promote moral theology that would not be constrained by "natural law" [sic! - S.S.]" (Guénois, 2015) and, as a consequence, it would allow to resign from the reference to the absolute norms, admitting a privileged place to judgement of conscience and life experience gained by a particular faithful. Here we can notice a radical contesting the moral rules of the catholic teaching taught by St. John Paul II in the encyclical Veritatis Splendor, in particular the moral norms dealing with sexuality and human procreation which were defined by St. Paul VI in Humanae Vitae and later confirmed in Familiaris Consortio. When the norms are not some arbitrary orders given by the power of human authorities but rather the expression of the truth about the good perceived by brain 
in a reasonable plan of the Creator, then they do not become constraint for freedom but rather remain the conditions of ecological realization which does not endanger the nature.

Cardinal Angelo Scola, while reflecting on ecology in the light of the Bible story of Job, presented a deep correlation between protecting the environment and nurturing a man. When a human brain strives to perceive the highest sense of things and is free to discover wisdom and order in the things that are, so the "me" of a human being emerges only in a harmonious way with the amazement over a "you". Ecology needs adequate and proper anthropology, not any anthropology nor its simplified version. Pope Francis expresses the same sense and utters almost the same words in his encyclical (LS 118). Thus, here we have the key necessary to avoid both the naturalism denying the first place to human being, and prometheism that makes him an irresponsible arbiter, who not only exploits the nature but also abuses it. To be able to protect the nature a man must, over all, embark on nursing themself. To find themselves, people must be able to be themselves not only in front of the Other, that is the Creator, but also in front of another being whom they dialogues with, a woman in case of a man, and a man in case of a woman. In anthropology of a man - a woman diversity, an order of nature imprinted in their bodies by the wisdom the Creator brings clarity (Scola, 2015).

When the constitutive anthropological diversity is negated, then negating nature itself and destroying the ability to love starts. It can be observed in the groups accepting gender ideology both in gender studies and in its precursors who perceive the sexual diversity as a social construction, therefore opting for a radical transformation of intimacy on the grounds of a plastic idea of the body (Giddens, 2006; Kuby, 2007). The body was supposed to be the subject to manipulation with hormones and surgical interference in the way that it would fulfil desires for pleasure of post-modern human beings. As a matter of fact, this violating demand for flexibility (infected by abuse) leads to the trivialisation of sexuality and the loss of immense riches of eros.

It contributes to destroying erosphere and its lethal infection, which causes the deterioration of the ability to find joy in love. The violation of the nature of the body and the disturbance of its rhythms (LS 71) is both a violation of love relations in search for fulfilment and their dynamic of a gift.

A desire should never strive for a temporary pleasure only, but for a longing for happiness which finds its complete horizon in an encounter with another person and in a good life that can be built with them. It is worth pointing out that Latin referent for happiness (felicitas) is combined with the idea of both: fertility and abundancy (Sondel, 1997: 376; Natoli, 2004). Happiness is the fertility of the power for distributing life around. Jesus defines the joy he promises to His disciples as: "I came that they [sheep] may have life, and have it abundantly" (Jn 10:10). It stands in opposition to the idea of a "fulfilment" that 
defines a limited measure for searched pleasure. Pleasure, in reality, has a symbolic meaning because it always refers to something more.

Thus, the body is not plastic but rather flexible, as José Noriega rightly notices. It is not able to accept each form because reacting to any artificial deformation will always direct it towards its natural and rational form, that is to aim at the realization of the desire for living in the fullness of sense (Noriega, 2012; Noriega, 2014).

Therefore, here comes the conclusion that the basic ecological care should include nursing moral virtues in ourselves, that is constant dispositions of our character and feelings which will allow for resettling relations between a man and a woman in the perspective of an authentic human fullness.

\section{Marital love and parenthood}

Having briefly looked at the anthropological foundations of the human ecology of conjugal love in a critical confrontation with what causes the contamination of the erosphere, it is now possible to focus on the most important aspect of the reflection under discussion, i.e. the relationship between human sexuality and procreation. It is undeniable that the realisation of sexuality between a man and a woman is by its very nature open to the possibility of conception and giving birth to offspring. However, since it has become possible to influence the complex physiology of reproduction in order to prevent conception not only by empirical methods, but also by means of preparations and tools offered by technology, a new question has arisen: from a moral point of view, is the "natural" relationship between sexuality and reproduction of any importance for human action? Is it just a simple statement of fact, as is the case with so many other issues concerning our physiology, or maybe - does this actual relationship carry some important meaning that should be respected in the name of the ecology of love?

Some theologians but also bishops and cardinals have long before put forward the suggestions of a radical revision of the teaching of Humanae Vitae and the whole Catholic teaching on sexual morality ${ }^{4}$. The ways of thinking and arguments which dominated the period before the encyclical of St. Paul VI are now returning. In reality, under the pretext of its "deepening" these voices deprive it from the doctrinal content and make us come back to the theological discussions which should have been considered already closed.

It was already back in the thirties and forties of the previous century in Germany and France that the demands were voiced to rediscover the personal character of human sexuality, which was rightly considered underappreciated in the traditional Catholic

${ }^{4}$ Cf. Opinions of moral theologians collected by the Pontifical Council for the Family in the volume Famiglia e Chiesa. Un legame indissolubile, Città del Vaticano 2015, where the teachings of Humanae Vitae on the indissolubility of marriage and homosexuality are openly challenged. 
teaching on morality 5 . The notion of "procreational aim" of marital act situated on the biological surface only, was subjected to "a unifying aim" being the only one of a personalistic value. As a consequence, parenthood was not perceived as the dimension imprinted in the nature of interpersonal sexual love. ${ }^{6}$ In this perspective bonum prolis, pushed to the background in the hierarchy of marital goods, is understood as the biological purpose of nature. Love interpreted ambiguously by the abstract personalism results in contradicting the natural forces. This vision hides the anthropological division between a person and nature, which identifies a person with a simple spiritual subject, gives it the complete power over the flesh in the perspective of achieving its own purposes.

At this point, a cultural context of the discussion over the encyclical of St. Paul VI mentioned before should be presented. In the sixties, a sociological vision got a voice in edgeways. It was influenced by certain alarming demographic slogans - like today's obsession of global warming - which stressed at the necessity of urgent birth control (the famous Report of the Club of Rome). An interesting thing is that, now when the West entered into the decadent phase resulting from demographic shortage a few decades ago, and when this tendency is being affected by globalization, some still operate in such categories, attributing experts the power of deciding for families how many children they should have.

Nowadays we must realize that such an attitude is short-sighted and there is a certain one-sided bias towards focusing only on the perspective of a couple themselves, and not the whole family, to establish the borders for the ethically permitted action to achieve an aim considered obvious, that means controlling the number of children. The limit is accepting as indisputable premise of the logic of control that sees in procreation only a physiological fact deprived of a personalistic meaning (Szpoton, 2021).

The answer of the Church given by St. Paul VI almost fifty years ago, which some would like to question, was clear and brave, it opposed the public opinion. In no 12 of the encyclical Humanae Vitae he states that "... the inseparable connection, established by God, which man on his own initiative may not break, between the unitive significance and the procreative significance which are both inherent to the marriage act. The reason is that the fundamental nature of the marriage act, while uniting husband and wife in the closest intimacy, also renders them capable of generating new life - and this as a result of laws written into the actual nature of man and of woman."

The laws which pope Montini refers to are not arbitrary orders of the Church authorities but they manifest the truth of the good which is the fruit of the Creator's wisdom

${ }^{5}$ For a critical reconstruction of the discussion on this topic, see the article: Mazzocato (2006, pp. 249275).

${ }^{6}$ For deep theological reflections pointing to the Trinitarian basis of this dimension, see: Sequeri (2018). 
written into the actual nature of man and of woman as a syntax of love. To understand this absurd of the call to pastoral mercy which would excuse exceptions in this context, we might try a test to check how would we react when using these ideas in medical practice. Would we consider merciful a doctor who would accept the unhealthy inclinations of a diabetic person and leave them to their own judgement of the conscience when they ate sugar?

To the individualistic and spiritual anthropology (one might say neogothic ${ }^{7}$, which in fact does not respect body and demands the power to manipulate it using technology, and a narrow concept of morality understood as a set of legislative rules which limit freedom), a clear and bright answer was given by St. John Paul II's "theology of the body" which opts for a deep integration of the person and their nature in the perspective of theology of love ${ }^{8}$.

"Theology of love" presents an anthropological basis of the ethics in the encyclical of St. Paul VI in which human body - a witness of the original love of the Creator, is the place where relations break the isolation of an individual to generate a person. In the encounter with a woman, a man discovers a groom's destination of his body to be fertile gift of himself. And only respecting this orientation to the gift, is the personalistic dignity of love protected, and it may be born not as a simple physiological result but as a gift of gift. It is important to spotlight that the body is not only a material reality which constitutes something a person "has", but is a part of something which a person "is". That is why the physiological dynamics of sexuality and procreation do not have just a biological meaning, though they indicate the basic meanings of the language of truly personal love, available to the human brain in an experience of love, through which they become enlightened and explored in the light of the theology of creation and the redemption of our body in Jesus Christ (Szpoton, 2021).

Thus, only through respecting the correlation between sexuality and reproduction can the value of the gift of marital unity be preserved and the dignity of human procreation be protected. It is not a "sacralization" of biological nature but rather the acknowledgement of a personal character of sexual love in the light of which emerges the practical truth about moral goods that are present in marital conduct. So the natural moral law is not a relic of fetishism from which one should be made free, but consists of the valuable truth which God's wisdom has imprinted in our body to bring us to the good of integrally personal love.

7 The Magisterium of the Church addresses the forms in which Gnosticism is proclaimed again today: Kongregacja Nauki Wiary (2018); Franciszek (2018, no 46-48).

8 This topic is explored in two studies written within the area of theological-moral research, operating at the Pontifical Institute of John Paul II for Marriage and Family Studies: Melina, Pérez-Soba (2012); Pérez-Soba, Gałuszka (2014). 


\section{Choices that strengthen love}

There remains a question to answer: What choices do really shape marital love in the light of anthropological foundations and the ethical rule of inseparable unity between the uniting and procreative meaning of a marital act?

It is clear that there are choices that instead of strengthening love, they pollute it. (Puccetti, 2013). Contraception - both chemical and mechanical in its different forms deprives marital acts from an integral meaning of personal gift open for life. This way it makes love contaminated, giving it an objectively egoistic direction, which is independent from subjective motivations and direct perception from the point of view of couples.

Hidden under an ideological language, though in reality more often the connection with abortion, it lowers the moral quality of some contraceptive practices, which have a character of early abortifacients. Being closed for life evolves with an ease into the negation of conceived life. Servant of God prof. Jérôme Lejeune named the pill RU 486 with a notion "human pesticide" because it infects not only a little embryo, but also the one who uses it. It works the way not only to annihilate, but also to destroy the whole environment of relations in which the choice of using it is made (Melina-Anderson, 2009). This is the reason why we should choose the other way which is, without doubt, much more demanding and difficult, though at the same time more human. In no 21 of Humanae Vitae Pope Montini says about the necessity of taking an effort of self-discipline and self-control, necessary for acquiring an ability to express marital love in truth. It is not about a technique which would excuse the lack of personal engagement but about the way of growing in the virtue of chastity. It is not a negation or self-mortification, but rather a stable source of personal maturity, which allows to live sexual drive in the dynamic aiming at a personal gift of love.

To respond to the great vocation to love and give birth to a new human life, the attitude of generous responsibility rooted in thankfulness is necessary. In such conducts Pope Francis sees the essence of that "ecological conversion", to which he encourages. The encyclical of human procreation by pope Paul VI discusses it in no 10, defining vital features of "responsible parenthood". There is a must of coming back to this teaching because of these misunderstandings being the result of today's dominant mentality, unfortunately also in the speeches of some personalities of the Church. The term "responsibility" is ambiguous only when it is identified simply with demographic control and its consequence of the necessity to refer to some efficient technical ways to perform it. In this way a subtle neoMalthusian mentality that understands procreation as a danger for the environment and even more, perceives a man as a cancer of the nature, postulating the fully prejudiced enmity towards multi-child families and towards young nations on other continents like Africa, Central America or Asia (cf. LS 50). This is the mentality which is born not on the peripheries of the world but in the centre of the "fed and deprived of hope" West that closes the sources 
of life. It looks suspiciously at people remaining in a fresh contact with energy sources and wants to impose on them ignoble laws of "healthy reproduction" as the condition of supporting their development. The Christian message of respect for the nature can never speak an ambiguous language of UN and other agencies which are striving for demographic control over young nations.

Cardinal Robert Sarah in an extended interview in harsh words warned about neocolonialism that also aims at polluting the erosphere of the other people. He said: "I believe that the enormous economic, military, technical and media influence of the West without God could be a disaster for the world. If the West does not convert to Christ, it could begin to paganise the whole world. (...) To contribute to their revival, countries of their ancient Christian tradition must rediscover their roots by embarking on the path of the new evangelisation" (Sarah, 2015, 209).

The features of an authentic procreational responsibility are born of the insight filled with admiration and thankfulness for the great gift of sexuality and its openness to life. Human ecology of love needs basically a contemplative attitude that is able to be surprised and consciously thank for the first and original and generous gift from the Creator: Laudato sii, mi Signore! - Be praised, my Lord! This way responsibility is not a domination full of unrest that aims at limiting the gift. In the creation and more in the Gospel of Jesus Christ the logic of overflow applies and we should never forget about this. Thus, responsibility implies enerous openness to the gift of life, (cf. Melina, 2008, pp. 113-128) and as such it cannot neglect God's providence which we, the lay too often forget and which the encyclical Laudato $s i^{\prime}$ does not unfortunately mention.

If there were any factors connected with physical or psychic health, economic or social difficulties imposing temporary limitations on the number of conceptions, then it should be performed with respect for the meanings imprinted in the core of marital act. The knowledge of natural fertility cycles and self-containment through self-restraint as the integral part of the virtue of chastity allow for living the procreational responsibility in harmony with God's plan and the integrally personal nature of love. The pauses in bodily expressed sexuality required in periodical practice of abstinence driven by chastity also constitute a part of the loving symphony of a married couple (Szpoton, 2021). Moreover, responsible parenthood consists of the engagement in a more and more precise study of physiological and biological laws of procreation. As wee as the care for formation which will make the study of fertility awareness methods easier and allow practicing them more effectively. 


\section{Summary}

When engaged in evangelization of love and marital intimacy, it is not difficult to be subjected to two accusations: either of having not enough mercy, or of presenting a too anachronistic mentality.

The above text answers the first accusation - true mercy is not an indulgence for the choices which are harmful to the environment of love, thus destroying erosphere. But rather, tolerance is an 'accomplice' to the things that do not allow to live the call to love in the right way. In the end of this path is resignation and contempt not only for a man and a woman, but also for God the Creator and the Redeemer. St. Paul VI wrote: "(...) it is an outstanding manifestation of charity toward souls to omit nothing from the saving doctrine of Christ; but this must be always joined with tolerance and charity" (HV 29).

As for the accusation of traditionalism, one must admit that the engagement on the field of human ecology is something totally opposite. The one who destroys erosphere bringing love to contamination, destroys future of a man and a woman. Running evangelisation of marital intimacy with accordance to an authentic human ecology means working for the benefit of the only vision that saves the personal dignity of love and procreation, and opens future perspectives for the humanity.

\section{List of abbreviations used in the footnotes:}

LS - Francis, Encyclical Laudato si'

HV - Paul VI, Encyclical Humanae Vitae

\section{Bibliography:}

Bauman, Z. (2013). Gli usi postmoderni del sesso, transl. P. Arganese, Bologna: Il Mulino.

Benedykt XVI (2011). Przemówienie w Bundestagu [Speech in the Bundestag], (ed. pol.),

L'Osservatore Romano 10-11, 38-41.

Benedykt XVI (2012). Presentazione degli auguri natalizi della curia

romana,http://w2.vatican.va/content/benedictxvi/it/speeches/2012/december/doc

uments /hf_benxvi_spe_20121221_auguri-curia.html (accesed: 5.01.2020).

Byung-Chul, H. (2013). Eros in agonia, transl. F. Buongiorno, Roma: Nottetempo.

Caffarra, C. (2006). Viventi in Cristo. Compendio della morale cristiana, Siena: Catagalli.

Franciszek (2015). Encyklika Laudato si'. W trosce o wspólny dom [Encyclical Letter Laudato si' on

Care our Common Home], Kraków: Społeczny Instytut Wydawniczy “Znak”. 
Franciszek (2018). Adhortacja apostolska "Gaudete et exsultate" o powołaniu do świętości w świeciewspótczesnym [Apostolic Exhortation "Gaudete et exsultate" on the Call to Holiness in Today's World], Częstochowa: Edycja Świętego Pawła.

Franciszek (2021). Przemówienie podczas obchodów 50. Światowego Dnia Ziemi [Speech at the 50th World Earth Day celebrations],https://www.vaticannews.va/pl/papiez/news/202004/papiez-audiencja-22-kwietnia.html (accesed: 2.07.2021).

Giddens, A. (2006). Przemiany intymności. Seksualność, miłość i erotyzm we wspótczesnychspołeczeństwach [Transformations of Intimacy. Sexuality, love and eroticism in contemporary societies], transl. A. Szulżycka, Warszawa: PWN.

Guénois, J.M. (2015). Synode de la famille: une réunion très discrète des réformateurs à Rome, https://www.leforumcatholique.org/message.php?num=779146 (accesed: 2.05.2021).

Guitton, J. (1995). L'amour Humain. Suivi De Deux Essais Sur Les Relations De Famille Et Sur Le Démon De Midi, Paris: Aubier.

Hilgers, T. (2004). "Disturbing Trends in the Health Care of Women, Children and Families,"

(in:) T. Hilgers (ed.), The Medical and Surgical Practice of NaProTECHNOLOGY, 1-17, Omaha (NE): PPVI Institute.

Jan Paweł II, (2017). Encyklika Centesimus annus [Encyclical Letter Centesimus annus], Wrocław: Wydawnictwo i Drukarnia Wrocławskiej księgarni Archidiecezjalnej TUM.

Kongregacja Nauki Wiary (2018). List "Placuit Deo" o niektórych aspektach zbawieniachrześcijańskiego [Letter "Placuit Deo" on certain aspects of Christian salvation], Rzym: LEV.

Kuby, G. (2007). Rewolucja genderowa. Nowa ideologia seksualności [The gender revolution. A new ideology of sexuality], transl. D. Jankowska, M. Urban, Kraków: Homo Dei.

Kuby, G. (2013). Globalna rewolucja seksualna. Likwidacja wolności w imię wolności, transl. D.Jankowska [The Global Sexual Revolution: Destruction of Freedom in the Name ofFreedom], J. Serafin, Kraków: Homo Dei.

Mazzocato, G. (2006). "Il dibattito tra Doms e neotomisti sull'indirizzo personalista", Teologia, 31, 249-275.

Melina, L. (2008). Azione: epifania dell'amore. La morale cristiana oltre il moralismo e l'antimoralismo, Siena: Cantagalli.

Melina, L., Anderson, C., (eds.) (2009). "L'olio sulle ferite". Una risposta alle piaghe dell'aborto edel divorzio, Siena: Cantagalli.

Melina, L., Pérez-Soba, J., (eds.) (2012). La soggettività morale del corpo (VS 48), Siena: Cantagalli.

Natoli, S. (2004). La felicità. Saggio di teoria degli affetti, Milano: Feltrinelli.

Noriega, J. (2012). “Fantasia e virtù: la conformazione dei desideri corporali”, (in:) L. Melina, J. Pérez-Soba, (edd.), Lasoggettività morale del corpo (VS 48), 173-185, Siena: Cantagalli.

Noriega, J. (2014). Enigmi del piacere. Cibo, desiderio e sessualità, Bologna: EDB. 
Paweł VI (1999). Humanae vitae [Encyclical Letter Humanae vitae], Wrocław: Wydawnictwo I Drukarnia Wrocławskiej Księgarni Archidiecezjalnej TUM.

Paweł VI, (1973). Anno santo: rinnovamento della coscienza personale, http://w2.vatican.va/content/paulvi/it/audiences/1973/documents/hf_pvi_aud_1 9731107.html (accesed: 28.01.2020).

Pérez-Soba, J., Gałuszka, P. (eds.) (2014), Persona e natura nell'agire morale, Siena: Cantagalli.

Puccetti, R. (2013). I veleni della contraccezione, Bologna: ESD.

Sarah, R. (2015). Dieu ou rien. Entretien sur la foi, Paris: FAYARD.

Scola, A. (2015). “Custodire il creato, coltivare l'umano. L'esperienza di Giobbe”, La Rivista del Clero Italiano, 11, 36-44.

Scola, A. (2015). Abitare il mondo. La relazione tra l'uomo e il creato, Milano: EMI.

Seewald, P. (2021). Benedykt XVI. Życie [Benedict XVI: A Life], Kraków: Społeczny InstytutWydawniczy "Znak".

Sequeri, P. (2018). “Humanae vitae, la libertà e la verità nel gesto d'amore", Avvenire, 10, $27-$ 28.

Sondel, J. (1997). Słownik łacińsko-polski dla prawników i historyków [Latin-Polish dictionary forlawyers and historians], ed. I, Kraków: Towarzystwo Autorów i Wydawców PracNaukowych "Universitas".

Szpoton, S. (2021). Naprotechnologia - cicha rewolucja [NaProTECHNOLOGY- A QuietRevolution], Kraków: Wydawnictwo Uniwersytetu Papieskiego Jana Pawła II. 